\title{
Broadband Wireless Access (BWA): Spectrum Refarming in Thailand
}

\author{
Settapong Malisuwan, Jesada Sivaraks, and Navneet Madan
}

\begin{abstract}
Spectrum Refarming is a spectrum management tool, which can be used to cater for new demand, increase spectrum efficiency or work towards international harmonization of spectrum usage. This paper indicates the process to determine Spectrum Refarming for providing Broadband Wireless Access (BWA) services in Thailand. However, this matter is still under consideration of the Spectrum Refarming Committee which works under the National Broadcasting and Telecommunications Commission (NBTC). Since the concept of Spectrum Refarming has not been fully materialized and NBTC has not yet reached a conclusion on this matter, this research paper is offers a preliminary study to inform and contribute knowledge to the telecommunications community on the concept of Spectrum Refarming.
\end{abstract}

Index Terms-Spectrum refarming, broadband wireless access (BWA), spectral efficiency.

\section{INTRODUCTION}

"Enterprises, Internet Service Providers, and Mobile Network Operators are searching for high capacity and cost-effective methods in transmitting data from multiple and separate locations at high speed"[1]. Contrary to wireless solutions such as BWA, copper and fiber optics solutions have "higher up-front costs, recurring leases from telecommunications companies, and also its lack of flexibility in comparison to wireless technologies in terms of implementation".[1]

Broadband Wireless Access (BWA) has surfaced to fill in the void from wired broadband technologies and "to provide a lower total cost of ownership than wired solutions, while at the same time maintaining or exceeding the reliability and performance of those permitted by wired technologies"[1].

In the context of Thailand, BWA provides two exceptional advantages over wired technologies. Firstly, this technology can be used to support fixed wireless broadband services in rural areas thereby diminishing digital divide. Secondly, a key advantage of BWA as a technology is that it permits mobile operators to use its existing infrastructure to provide wireless services thereby incurring in a minimum cost of investment.

BWA was operated since November 2000 [2] and NBTC has already issued "the Declaration of Principles for the Allocation of Spectrum for Trial" and has joined NECTEC study guide on the utilization of BWA technology which started in August 2006. Subsequently, "The Declaration of Radio Spectrum Regulation on Broadband Wireless Access

Manuscript received January 14, 2013; revised March 27, 2013.

The authors are with the Telecommunications Commission of NBTC, Bangkok, Thailand (e-mail: Settapong.m@nbtc.go.th, jesada.s@nbtc.go.th, navneet.m@nbtc.go.th).
(BWA)" was announced in January 2007. Further, the testing of BWA was completed June 2007 which lead to the start of BWA trials hence, 20 cases was tested and completed from January to September 2008. The operator was permitted to use frequencies in the ranges 2300-2400 MHz, 2500-2520 $\mathrm{MHz}, 2670-2690 \mathrm{MHz}, 3300-3400 \mathrm{MHz}$ and 3400-3700 $\mathrm{MHz}$ for experimentation of BWA on the condition that any technology (neutral technology) or method could be used in these tests as long as it complies with international standards set for wireless technologies.

NBTC assigned the Spectrum Refarming committee to manage all spectrum refarming related issues and it was bestowed the right and responsibility from NBTC to determine and put in writing the Spectrum Refarming Master Plan. Apart from determining and creating the Spectrum Refarming Master Plan, the committee is also responsible for reporting and summarizing rational decisions of NBTC which verifies what matters should be enforced. Spectrum Refarming Committee decisions jointly with the final decision from NBTC can be used to bring about the cancellation of all licenses within the stated spectrum ranges.

In order to follow the rules and regulations of NBTC, Spectrum Refarming Committee has set and prioritized criteria according to its importance in order to propose correct actions to NBTC and also use these criteria to make a decision on Spectrum Refarming matters. Consequently, Spectrum Refarming Committee has determined that BWA is extremely significant and should be enforced without delay.

\section{IMPORTANCE OF SPECTRUM REFARMING}

Exponential demand of spectrum has emerged from several industries simultaneously thereby putting a strain on the already inadequate supply of spectrum. Presently, spectrum scarcity is a critical issue faced worldwide.

To overcome the issue of spectrum scarcity, regulators have to ration its usage by allocating spectrum to highest value generating technologies. Moreover, this issue could also be resolved by using advanced technologies to increase the capacity of frequency ranges that have lower demand because of its limited capacity to support a more advanced or higher value generating technologies. Thereby, advanced technologies can be used to increase the productivity of lower demand frequencies in order to increase spectrum availability. As a result, these frequencies can therefore be allocated to users. In other words, spectrum refarming is the key solution behind spectrum scarcity since it can be defined as the reassigning or recovering spectrum from its existing users to new users that will adopt the spectrum for higher value generating technologies or more spectrally efficient technologies. 
According to the report on Spectrum Refarming and Secondary Trading in a Changing Radio Communications World "refarming is a spectrum management tool, which can be used to cater for new market demand, increase spectrum efficiency or work towards international harmonization of spectrum usage." [3]. If the Spectrum Refarming process has taken place naturally as a result of movement towards more effective and efficient technology from the less efficient one and is within the interest of the official incumbent user then it is less problematic to the spectrum management authorities. However, in cases where existing users are not making efficient uses of the spectrum then existing users should be required to leave that band and remove their old inefficient systems so that it could be reallocated to users who will use it for higher value generating technologies. Hence, further extension should not be provided for existing users that make inefficient usage of the spectrum when the license expires [4].

Under such cases no incentives or any other refarming measures will be required, but if the refarming is forced i.e. forced removal of existing frequency assignments which is against the interest of the existing user then the process becomes problematic and refarming funds or other forms of pricing incentives will be required. It is obvious that when Spectrum Refarming has been forced upon the existing or incumbent user; a particular amount of compensation has to be paid to the user and the user should be informed well in advance.

\section{ACTIONS OF SPECTRUM REFARMING COMMITTEE AND OTHER RELATED KEY ISSUES.}

1) National Table of Frequency Allocations was scrutinized in order to reach a conclusion for this study. International Telecommunication Union (ITU) has also determined that frequency range of $2500-2690 \mathrm{MHz}$ should be shared between telecommunication and broadcasting services. Moreover, if the band is used to transmit both radio and broadcasting signals, decisions of this frequency range must taken by both National Telecommunications Commission and National Broadcasting Commission. Apart from this, Spectrum Refarming Committee should set a criteria and the time frame required for spectrum refarming for frequency range $2300-2400 \mathrm{MHz}$ due technical difficulty faced in the past which has limited this band only for TDMA technology and public payphone usage.

2) Five standards of $3 \mathrm{G}$ Mobile Cellular Communications are approved and recommended by IMT-2000 standard, which is part of ITU-R M.1457 recommendation. Subsequently in 2007, BWA technology was then accepted by the ITU-R M.1457 recommendation. Practically it should be acknowledged that BWA and IMT-2000 has been developed through different types of technology but both have the end result that is a more advanced and higher speed for internet access. Therefore, within the World Radiocommunication Conference 2007 (WRC-2007) discussion, it was confirmed that BWA technology may eventually reach the same standard as IMT-2000

3) Broadband Wireless Access (BWA) has been defined in
ITU-R F.1399 Recommendation as wireless connection with speed that is higher than $1.544 \mathrm{Mbps}$. As a result, WIMAX technology fits this definition; it is also a part of BWA.

\section{RESUlT FROM SPECULATION AND ANALYSIS}

Spectrum Refarming Committee has set the criteria and time frame for allocating spectrum band $2300 \mathrm{MHz}$ which are as follows

1) In cases where incumbents hold frequency licenses which do not have a set license expiration date, spectrum refarming will be solely dependent on the negotiation between NBTC and the license holder. However, negotiations could be extremely time consuming and it is highly difficult to reach a conclusion for this matter.

2) If NBTC determines that there is a need for spectrum refarming for the frequency range 2300-2400 MHz, NBTC must follow the process that is declared within the Spectrum Refarming Action Plan. Moreover, if all procedures comply with NBTC regulations and declaration, the license cancellation of the existing users can be done immediately.

3) Based on the regulations of NBTC, it can be determined that compensation of Spectrum Refarming should not be more than the license fee and Spectrum frequency should be used according to proportion of the remaining time frame in the license. This also takes into consideration the entire amount invested by the existing license holder. Compensation is determined by the economic cost of the license but should not be more than the total value of the spectrum being refarmed. Therefore, negotiations between the NBTC and spectrum user on compensation is extremely important and this should be resolved before reallocating the spectrum.

4) Based on the study of Spectrum Refarming Committee, 2300-2400 MHz band users can be categorized into two groups which are private sector and National Security Agency [5], [6]. For the first group, the private sector utilizes the frequency for internal coordination within its organization and also for serving its users. Therefore, Spectrum Refarming could affect end users served by the private firm. The second group is National Security Agency that utilizes 2368-2400 MHz Spectrum Refarming may result in negative impact on the national security. If there is a need to enforce this process in a short period, there has to be compensation and creation of benefit in order to reimburse the users affected.

5) License holders that use frequencies in areas such as Gulf of Thailand and Andaman Sea will not be affected by Spectrum Refarming in 2300-2400 MHz. Hence, the existing user of this spectrum should be permitted to utilize the spectrum in a particular area. However, NBTC needs to set a regulation for this unusual case to ensure that the utilization of spectrum must be limited only to that particular area. Therefore, the telecommunication networks should not be expanded beyond the Gulf of Thailand or Andaman Sea. As a result, this should be enforced as a regulation.

6) When spectrum license do not have a set license period, this becomes critical issue in implementation of 
spectrum refarming since these users have to be compensated. Compensation could be extremely costly as there is a high economic cost since spectrum is valuable national resource. Therefore, spectrum usage must be managed to ensure spectrum efficiency. Moreover, in 2012, Thailand has implemented first spectrum auction to allocate license, and new licenses that will be allocated after 2012 onwards will have license period. This will lead to high spectrum efficiency in Thailand and it also complies with international standards set by well-accepted international telecommunication organizations including ITU.

\section{RECOMMENDATIONS OF SPECTRUM REFARMING COMMITTEE}

From the consideration and analysis in all aspects possible, the committee has determined the following criteria.

1) NBTC should conduct the negotiation under the criteria or conclusion accepted by both the negotiating parties.

2) NBTC will announce the frequency users in the Gulf of Thailand region that uses $2300-2400 \mathrm{MHz}$ to limit the use of the frequency only in that region and they are not permitted to expand their network towards the land.

3) NBTC will inform the users of frequency 2300-2400 $\mathrm{MHz}$ that they are not allowed to bring components for their original equipment into Thailand starting from the day of the announcement. They will also be informed of the time limit for the radio telecommunications equipment clearly and also that they are not permitted to expand their network.

4) NBTC will announce that every Universal Service Obligation (USO) project cannot expand or utilize frequencies outside the scope of the project and they are not allowed to expand their network.

5) NBTC should set a fund to compensate the allocation and determination of Spectrum Refarming in order to support the process of determining and allocation of Spectrum Refarming with ease and justice according to the regulation of NBTC.

6) NBTC should finalize the standard to develop and support users that use Radio frequencies so they will collaborate in returning the license to use the frequencies for the benefit of the society as a whole and for the development of the Thai Telecommunications industry.

\section{CONCLUSION}

Spectrum Refarming is a new but critical process for Thailand. Without Spectrum Refarming, further development of telecommunications in Thailand could be extremely difficult. As mentioned, Spectrum Refarming Committee has proposed and prioritized significant actions that should be taken by NBTC in order to conduct Spectrum Refarming in Thailand. As BWA is critical to the advancement of telecommunications industry in Thailand, spectrum availability for this technology should be made through spectrum refarming. Spectrum refarming committee has therefore proposed that license period should be set for all spectrum licenses. Overall, spectrum refarming will allow the reallocation of spectrum from existing less efficient uses to higher value generating uses, thereby resulting in higher spectral efficiency which will further lead to a more advanced telecommunications industry in Thailand.

\section{ACKNOWLEDGMENT}

The authors in this paper would like to thank the reviewers for their excellent recommendation. We would also like to provide special thanks to the Spectrum Refarming Committee within National Broadcasting and Telecommunications Commission for their active participation and their recommendations for spectrum refarming.

\section{REFERENCES}

[1] D. Pareek, "Economics of WiMAX," in the Business of WiMAX, 1s Edition, Chichester, UK: Wiley, 2007, ch 8, pp. 173-210.

[2] J. Burns, P. Marke, F. L. Borgne, and R. Rudd. (June 2004). Study on Spectrum Management in the field of Broadcasting: Implications of Digital Switchover for Spectrum Management. [Online]. Available: http://ec.europa.eu/information_society/policy/ecomm/doc/library/ext studies/spectrum_mgmt_bc_dswo/final_report_v3.pdf

[3] Messolonghi. (September 2002). Refarming and Secondary Trading in a Changing Radio Communications World. ECC Report 16(1) [Online]. Available: http:// www.ictregulationtoolkit.org/en/Document.2724.pdf

[4] D. Hatfield. (February 2005). Introduction to spectrum management reform. Presented at the GREX Virtual Conference. ITU/BDT Regulatory Reform Unit 28. [Online]. Available: http://www.ictregulationtoolkit.org.

[5] J. M. Peha, "Relieving spectrum scarcity through real-time secondary markets," presented at International Symposium on Advanced Radio Technologies, sponsored by NTIA, US Department of Commerce, Boulder, CO, March, 2003

[6] J. M. Peha, "Approaches to spectrum sharing," Communication Magazine, IEEE, vol. 43, no. 2, pp. 10-12, Feb. 2005.

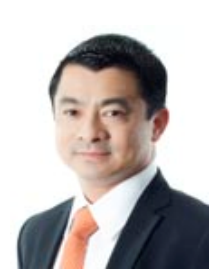

Settapong Malisuwan was born on 24th March 1966 in Bangkok, Thailand. He received his $\mathrm{PhD}$ in electrical engineering (telecommunications), specializing in mobile communication systems from Florida Atlantic University (State University System of Florida), Boca Raton in 2000. He received an MSc in electrical engineering in mobile communications system, from George Washington University in 1996, an MSc in electrical engineering in telecommunication engineering from Georgia Institute of Technology in 1992 and a BSc in electrical engineering from the Chulachomklao Royal Military Academy, Nakhon-Nayok, Thailand in 1990. He served in the Royal Thai Armed Forces for more than 25 years and is currently the Vice Chairman of National Broadcasting and Telecommunications, Bangkok, Thailand. His research interests are in efficient spectrum management and Telecommunications policy and management in Thailand. Col. Dr. Settapong Malisuwan Settapong Malisuwan is currently the Elected Vice Chairman and Board Member in the National Broadcasting and Telecommunications Commission, Thailand

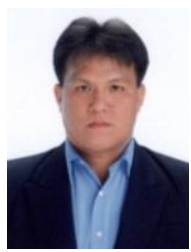

Jesada Sivaraks was born on $12^{\text {th }}$ May 1970 in Bangkok, Thailand. He received his MSEE degree from Oklahoma State University in 1996 and BEng from King Mongkut"s Institute of Technology, Thailand. He completed his PhD in electrical engineering at Florida Atlantic University, Boca Raton, FL in 2001. Since 2011, he has been working in National Broadcasting and Telecommunications Commission as the Secretary to the Vice Chairman. His $\mathrm{PhD}$ work is on the system aspects of Bluetooth, WLAN and Mobile IP/CDPD. His current research interests are in telecommunication planning and related system analysis and efficient spectrum management. He is a member of Tau Beta Pi, Florida Epsilon and was an Honorary Advisory's Chairman of Science \& Technology committee of Parliament in 2009 
Navneet K. Madan was born in Bangkok, Thailand on 22nd April, 1987. She received her Bachelor of Business Administration in international business management from Mahidol University in 2008, and received Master of Science degree in strategic management and marketing, Middlesex university, London, United Kingdom. She has been working as an Assistant to Vice Chairman in National Broadcasting and
Telecommunications, Bangkok, Thailand since January 2012. Her research interests are in Spectrum Management Strategic Flexibility, Market Orientation and Environmental Uncertainty in Fast Clockspeed Industries. 